\title{
Temporal analysis of water-energy nexus indicators for hydropower generation and water pumping in the Lower Blue Nile Basin
}

DOI:

10.1016/j.jhydrol.2019.124085

\section{Document Version}

Accepted author manuscript

Link to publication record in Manchester Research Explorer

Citation for published version (APA):

Basheer, M., \& Ahmed Elagib, N. (2019). Temporal analysis of water-energy nexus indicators for hydropower generation and water pumping in the Lower Blue Nile Basin. Journal of Hydrology, 578, 124085.

https://doi.org/10.1016/j.jhydrol.2019.124085

\section{Published in:}

Journal of Hydrology

\section{Citing this paper}

Please note that where the full-text provided on Manchester Research Explorer is the Author Accepted Manuscript or Proof version this may differ from the final Published version. If citing, it is advised that you check and use the publisher's definitive version.

\section{General rights}

Copyright and moral rights for the publications made accessible in the Research Explorer are retained by the authors and/or other copyright owners and it is a condition of accessing publications that users recognise and abide by the legal requirements associated with these rights.

\section{Takedown policy}

If you believe that this document breaches copyright please refer to the University of Manchester's Takedown Procedures [http://man.ac.uk/04Y6Bo] or contact uml.scholarlycommunications@manchester.ac.uk providing relevant details, so we can investigate your claim.

\section{OPEN ACCESS}


2 hydropower generation and water pumping in the Lower Blue

${ }^{1}$ Institute for Technology and Resource Management in the Tropics and Sub-tropics (ITT), Technische Hochschule Köln, Cologne, Germany Manchester, Manchester, United Kingdom 
Graphical Abstract (for review)

\section{Graphical abstract}

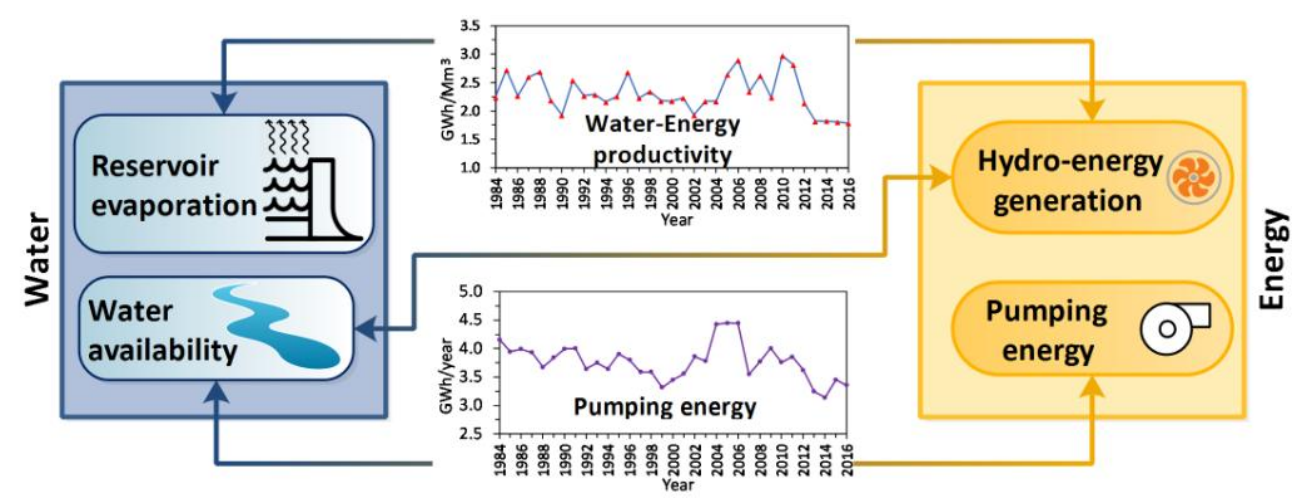




\section{$1 \quad$ Highlights}

2

- A daily Blue Nile model is utilized to explore nine indicators for water-energy nexus

- Time series of hydropower generation and water pumping indicators are analyzed

6

- Both the water availability and dam operation influence the nexus indicators

- A shift in regime was found in 2013 for most of the indicators due to the heightening of the Roseires Dam

- Turbines of higher capacity in the Roseires Dam will allow better utilization of its hydropower potential 


\section{Abstract}

This study performs a temporal analysis for nine water-energy nexus indicators for hydropower generation and irrigation water pumping in the Lower Blue Nile Basin. The nine indicators are water-energy productivity, firm daily energy generation, percentage of days at power generation capacity, variation in daily energy generation, annual energy generation, highest daily pumping energy, lowest daily pumping energy, variability in daily pumping energy, and annual pumping energy. The Blue Nile, a major tributary of the Nile, within Sudan is taken as an example to demonstrate application and interpretation of the temporal evolution of the nine nexus indicators. A daily calibrated and validated water allocation model for the Blue Nile is used to construct time series of the nine indicators from 1984 to 2016. Time series analysis is performed to detect significant trends and regime shifts in the nine indicators. The analysis reveals that the heightening of the Roseires Dam in 2013, one of the dams in the study region, resulted in significant shifts in annual energy generation, percentage of days at power generation capacity, variation in daily energy generation, waterenergy productivity, and annual pumping energy. The significant shift (an increase in this case) that occurred in the percentage of days at power generation capacity indicates that turbines with higher capacity could be installed in the Roseires Dam to utilize its hydropower potential more efficiently. It is also shown that annual hydro-energy generation in the study region is dependent on water availability in the dry season (November to June). Temporal analysis of the nexus indicators demonstrates robustness to detection of significant human interventions in the hydrological system. Understanding the temporal dynamics of the waterenergy nexus is key to efficient utilization of water and energy resources, especially in a basin like the Nile where considerable alterations to the headwaters are underway. 
40 Keywords: Hydropower generation; irrigation water pumping; regime shift detection;

41 RiverWare; Blue Nile Basin; Sudan

\section{Introduction}

Water and energy are quintessential components for sustainable development and growth. The demands for them are escalating at high rates due to population growth, urbanization, and economic development. By the year 2050, global energy demands are expected to increase by $50 \%$ and water withdrawals are expected to grow by $50 \%$ and $18 \%$ in the developing and developed countries, respectively (Flammini et al., 2014). Moreover, water and energy systems contribute considerably to climate change, and they are also highly susceptible to nonstationarity in climate (Howells et al., 2013). The growing demands for water and energy against scarcity, supply crisis, and management failure of these resources have increased the concern about their intimate interlinks (Al-Saidi and Elagib, 2017). Water and energy resources are intrinsic to economic planning and developing resources-related policies (Gleick, 1994), especially in a world that is facing inequality in access to resources

54 (Simpson and Jewitt, 2019). Integrated analysis of water and energy systems is central to electricity planning and comprehension of water constraints (Ackerman and Fisher, 2013).

Highlighting the gap between the current and optimal utilization of water and energy resources can be achieved by illustrating the flows of the two resources and their crossconnections with other sectors (Liu et al., 2019).

Understanding the water-energy nexus, i.e. connections between water and energy, is essential. For instance, the impacts of changes in precipitation and temperature regimes on water and energy security are likely where the provision of reliable water and energy supplies

62 are going hand-in-hand, e.g. where hydropower plants utilize water to power the electricity

63 grid and the grid, in turn, powers the pumps that supply water (Romero-Lankao et al., 2018). 
64 Based on an evaluation of the nexus of interventions on urban water and energy use, Engström et al. (2017) reveal that interventions yielding the greatest potential for reductions

66 in energy use and greenhouse gas emissions are not necessarily the most water-conserving ones and vice versa. A nexus perspective is, therefore, a starting point for identifying synergies, trade-offs, and solutions that consider water use across different sectors and scales (Rasul et al., 2019). Understanding the relationship between water and energy resources can be improved by quantitative analyses of their nexus (Dai et al., 2018). In assessing this nexus, the ultimate goal is to inform "strategies, policy measures, planning, and institutional set-up or interventions" (Flammini et al., 2014).

Nexus narratives have been used to both support and oppose large-scale hydropower development and expansion of irrigation in transboundary river basins (Lebel and Lebel, 2018). Large river basins with their various human pressures, such as agricultural activities, hydropower development, and dam-impacted catchments, result in ecological risks and thus require accounting for the nexus approach in the planning for sustainable river management and development (Keskinen et al., 2016, 2015; Kibaroglu and Gürsoy, 2015; Nilsson et al., 2005). At least, 153 large river systems can be identified in Latin America, Africa, Asia, and Australasia where the impacts of economic activities (e.g., irrigation, hydropower generation) are too strong (Nilsson et al., 2005). Based on an analysis of the relationship between growth in population, dam development, and the nexus resources, Chen et al. (2016) and Shi et al. (2019) argue in favor of an abundant need for multi-purpose dam construction in the foreseeable future to deal with the socio-economic problems in developing and least developed countries. Nevertheless, they also state explicitly that human beings should at the same time "think more about how to better construct, operate, and maintain dams and reduce their negative impacts" (Chen et al., 2016). For instance, calculating the loss of water resources from multi-purpose dams through evaporation from the surface of reservoirs is 
complicated by the mode of dam operation, which is in turn determined by economic criteria, upstream and downstream demands for water, and ecological requirements (Gleick, 1994). Adopting a nexus approach allows examining the different benefits and losses in the face of dam operation modes and elucidating the challenges to reaching win-win situations across a nexus in large river basins (Jalilov et al., 2016).

To carry out a rapid nexus appraisal and assess the performance in terms of resource use efficiency, indicators specific to each type of intervention can be quantified using specific tools (Flammini et al., 2014). Development and application of indicators for the nexus enable improved analysis, understanding, and addressing of the inextricable interlinkages between water supply and energy production in order to enhance cross-sectoral coherence and manage the nexus challenges effectively (Basheer and Elagib, 2018; Larsen and Drews, 2019; Rasul, 2014). In other words, designing and using nexus indices to summarize the effects of multiple complex resource processes can be useful in measuring progress toward policy objectives (Lawford et al., 2013). Nawab et al. (2019) developed a nexus strength indicator to present a unified accounting of multiple ecological resources usage of energy and water in the urban industrial system. Using indicators of water-energy nexus, Elagib et al. (2019) showed how hydrological phenomena, such as drought and flood, can determine the state of hydropower generation from dams in an urban environment. Analysis of nexus indicators can help minimize the water and energy consumption and maximize economic productivity (El Gafy et al., 2017). A review carried out by Dai et al. (2018) has found a few studies that include historical analyses of the variation of the water-energy nexus. Towards optimized outcomes and minimized risk related to the nexus, these analyses can provide useful information for understanding the nexus, building reasonable scenarios, and educating and guiding actions and policies by decision makers (Dai et al., 2018). Studying the historical water-energy nexus 
113 indicators of storage dams through observed data and/or modeling provides a solid ground for

114 setting solutions for hydro-energy generation and satisfying water demands (Si et al., 2019).

115 Emerging data generation and processing technologies can help manage the water and 116 energy systems more efficiently and sustainably (Helmstedt et al., 2018; Lawford et al., 2013;

117 Lawford, 2019). In order to inform more effective national policies and regulations, the

118 importance of modeling in generating the nexus data is emphasized (Bazilian et al., 2011).

119 Modeling could help decision-makers and stakeholders make informed decisions for

120 satisfactory water-energy nexus management (Zhang and Vesselinov, 2016). For instance,

121 modeling the nexus has attracted attention in recent years to enable identification of strategies

122 of water and energy resources capture while minimizing negative impacts at national and/or

123 sub-national levels (Pittock et al., 2016; Basheer et al., 2018; Basheer and Elagib, 2018;

124 Stamou and Rutschmann, 2018; Si et al., 2019). In this regard, a quantitative stochastic

125 analysis of competitive and cooperative relationships between energy and water systems has

126 shown that renewable energy production can increase while both power generation costs and

127 carbon dioxide emission can decrease under integrated management of hydropower and water 128 supplies (Hu et al., 2018).

Motivated by the above backdrop, the present research aims at producing actionable

130 information by (1) developing and applying some indicators of water-energy nexus using

131 water allocation modeling and (2) performing temporal analysis of these indicators over

132 several decades. This study demonstrates that temporal analysis of water-energy nexus

133 indicators could help identify significant changes in the water and energy systems and venues

134 for efficient resource use. The research is carried out for the Blue Nile in Sudan, which is

135 characterized by multi-purpose storage dams for hydropower generation and irrigation water

136 supply. The selection of the Blue Nile in Sudan with its two dams, the Roseires and the

137 Sennar (Fig. 1), is justifiable by the high reliance of the rapidly growing populations of the 
138 downstream countries, Sudan and Egypt, on the Nile water and the expected challenges for

139 consistent provisioning of water resources that climate change is projected to present due to

140 more variable flows (Conway, 2017). This river plays a paramount role in the economy of

141 Sudan by providing water to irrigate vast croplands over several schemes, producing

142 hydropower and reducing flood damage (Goor et al., 2010; Omer et al., 2015). The Blue Nile

143 Basin is considered by Al-Saidi and Hefny (2018) as a "resource basin" for which the nexus 144 approach can highlight key neglected issues on interlinked resources. What makes this study

145 also important is a result found by Endo et al. (2017), who reviewed 37 projects dealing with 146 nexus research. They found that only $7 \%$ of the projects in Africa had a focus on water147 energy interconnections.

\section{2. Study area}

Fig. 1 shows the location and main characteristics of the study area. Herein, the Blue Nile Basin within Sudan is taken as a case study to demonstrate the application of waterenergy nexus indicators and measures on hydropower generation and water pumping. The

152 Blue Nile is one of the main tributaries of the Nile River and has a drainage area of around $153310,000 \mathrm{~km}^{2}$. It is geographically shared between Ethiopia and Sudan with around $64 \%$ and $36 \%$ of the basin area in each of the two countries, respectively. It originates in Ethiopia from around $4000 \mathrm{~m}$ asl, flows through the Ethiopian Plateau while other tributaries join the mainstem, and enters Sudan at around $500 \mathrm{~m}$ asl (Sutcliffe and Parks, 1999). The Blue Nile

157 continues its journey in Sudan and meets the White Nile - a main branch of the Nile River at the Capital of Sudan, i.e., Khartoum, at around $375 \mathrm{~m}$ asl. Two major tributaries join the Blue Nile in Sudan, namely the Dinder and the Rahad rivers. The two streams start in

160 Ethiopia and contribute together around $4.6 \%$ of the total inflow of the Blue Nile on average.

161 Downstream Khartoum, the flows of the Blue Nile and the White Nile combine to form the 
162 Main Nile, which merges with the Atbara River and cruises northwards through the desert landscapes of Northern Sudan and Egypt before ending in the Mediterranean Sea. the Sudanese-Egyptian border (NBI, 2012; Sutcliffe and Parks, 1999). Furthermore, the flow of the Blue Nile has high inter- and intra-annual variabilities. As Fig. 2 shows, the total annual flow of the river, which is measured at the outlet of the basin, ranges approximately between 30,000 and 71,000 $\mathrm{Mm}^{3}$ with a mean of around 53,000 $\mathrm{Mm}^{3}$. The two extremes occurred in 1984 and 1988, which were directly related to very low and very high rainfalls, respectively (Conway and Hulme, 1993; Davies and Walsh, 1997; Sutcliffe et al., 1989).

As Fig. 1 presents, the study area contains several dams and irrigation schemes that are currently in operation: the Roseires and the Sennar dams; the Gezira and Managil, the Gunied, the Suki, the North West Sennar, and the Rahad 1 irrigation schemes. Table 1 shows

174 the main characteristics of the Roseires and the Sennar dams. Infrastructure development in 175 the study area started as early as 1925 with the construction of the Sennar Dam and the commencement of the Gezira Scheme (MoIHES, 1977). The primary purpose of the Sennar Dam is to supply the Gezira Scheme with irrigation water by gravity. The Gunied Sugar Scheme was constructed in 1962. A pumping station, located on the Blue Nile reach upstream

179 Khartoum, extracts the irrigation water of the Gunied Scheme from the Blue Nile.

180 Infrastructure development in the study area progressed in 1966 with the completion of the 181 first stage of the Roseires Dam and the Managil extension of the Gezira Scheme (MoIHES, 1977). The heightening of the Roseires Dam (i.e., the second stage) was completed in 2013 to add 10 m of elevation (DIU, 2016). The purpose of the Roseires Dam is to supply the Gezira

184 and the Managil schemes with irrigation water and to generate hydropower (MoIHES, 1977).

185 The Roseires Dam supplies the two schemes through water releases to the Sennar Dam, 
187 during the 1970s: the Suki was completed in 1971; the North West Sennar was completed in 188 1972; the Rahad 1 was completed in 1977 (MoIHES, 1977). The three schemes abstract their

189 irrigation water from the Sennar Reservoir via pumping stations, with the Rahad 1 Scheme

190 receiving part of its irrigation water from the Rahad River (MoIHES, 1977).

191 3. Methodology

This section starts with formulation and discussion of the water-energy nexus indicators. Then, a description is provided on the river basin model of the Lower Blue Nile, which has been used to develop time series for some of the indicators. Third, the methods used for temporal analysis of the time series of the water-energy nexus indicators are shown. Lastly, the data sources of the Lower Blue Nile model are presented.

\section{1. Water-energy nexus indicators}

Fig. 3 demonstrates the water-energy nexus components considered herein which are: hydro-energy generation from storage dams, energy required for pumping water from rivers and storage reservoirs, reservoir evaporation, and water availability. The figure also shows some indicators for the interlinkages of the four nexus components. The following parts of this section describe the interlinkages and indicators.

\section{1. 1. Hydro-energy generation and reservoir evaporation}

Hydro-energy generation is a process that converts the velocity or potential energies of water into mechanical energy and then electricity using turbines and electromagnetic generators. Whether the velocity or potential energy of water is converted into electricity or not depends on the type of hydropower plant. Storage dams increase the potential energy of water by increasing the difference in water level between upstream and downstream the dam and then converts the potential energy into electricity by releasing water through hydropower 
210 turbines. On the other hand, run-of-river plants primarily convert the velocity energy of water

211 into electricity. In this study, we only considered hydro-energy generation from storage dams.

212 Several studies classically viewed hydro-energy generation from storage dams as a non- or a

213 semi non-consumptive water user (Perry, 2011; Sadoff and Grey, 2002). However, raising the

214 potential energy of water through reservoir storage increases the water surface and,

215 consequently, increases water losses to the atmosphere through evaporation. Based on this

216 fact, several recent studies analyzed the water footprint of hydropower generation by

217 accounting for reservoir evaporation losses (Bakken et al., 2017; Basheer and Elagib, 2018;

218 Larsen and Drews, 2019). In this study, the Water-Energy Productivity (WEP), a water-

219 energy nexus indicator for hydropower generation developed by Basheer and Elagib (2018),

220 was explored and applied. They defined WEP as the amount of hydro-energy generated per each unit of water lost to evaporation. The WEP is calculated on annual basis by dividing the total annual energy generation by the total annual evaporation losses of a hydro-energy generation system, as shown by Equation 1 (Basheer and Elagib, 2018).

$$
W E P_{A}=\frac{\sum_{i=1}^{Y} H E_{i}}{\sum_{i=1}^{Y} E V_{i}}
$$

where $W E P_{A}$ is the annual Water-Energy Productivity $\left(\mathrm{GWh} / \mathrm{Mm}^{3}\right), H E_{i}$ is hydro-energy generation in the $i^{\text {th }}$ day of the year $(\mathrm{GWh}), E V_{i}$ is reservoir evaporation in the $i^{\text {th }}$ day of the year $\left(\mathrm{Mm}^{3}\right)$, and $Y$ is the number of days in the year.

\section{1. 2. Hydro-energy generation and water availability}

Water availability and hydro-energy generation from storage dams are inherently

230 related since the abundance or scarcity of water determines how much of it could be stored or passed through the hydropower turbines (Hamududu and Killingtveit, 2012; Van Vliet et al., 2016). Subject to the purpose(s) and the operating policy of the storage dam, high river flow enables sustaining high reservoir water levels, increasing the potential energy of water, 
234 passing high amounts of water through the hydropower turbines, and elevating hydro-energy

235 generation. In the case of multipurpose storage dams that generate hydro-energy and supply

236 water, the location of water abstraction, i.e., upstream or downstream the dam, is another

237 factor that affects hydro-energy generation. Water abstraction downstream of a dam increases

238 hydro-energy production because it enables energy generation before water abstraction. On

239 the other hand, water abstraction upstream of a dam reduces hydro-energy generation. In this

240 study, several indicators and statistical measures were explored and analyzed to understand

241 the interlinkages of hydro-energy generation and river flow. Those indicators are annual

242 hydro-energy generation (Equation 2), firm daily energy generation (Equation 3), variability

243 in daily energy generation (Equation 4), and percentage of days at energy capacity (Equation

$2445)$.

245

$$
H E_{A}=\sum_{i=1}^{Y} H E_{i}
$$

$F D E=\min \left\{H E_{1}, H E_{2}, H E_{3}, \ldots, H E_{Y}\right\}$

$$
C V_{H E}=\frac{\sqrt{\frac{\sum_{i=1}^{Y}\left(H E_{i}-\overline{H E}\right)^{2}}{Y-1}}}{\overline{H E}}
$$

$$
P D E C=\frac{\sum_{i=1}^{Y} \begin{cases}1 \text { if } & H E_{i}=H E_{c} \\ 0 \text { if } & \text { otherwise }\end{cases} }{Y} \times 100
$$

where $H E_{A}$ is the annual hydro-energy generation $(\mathrm{GWh}), H E_{i}$ is hydro-energy generation in the $i^{\text {th }}$ day of the year $(\mathrm{GWh}), Y$ is the number of days in the year, FDE is the firm daily energy in a certain year (GWh/day), $C V_{H E}$ is the coefficient of variation of daily energy generation in a certain year, $\overline{H E}$ is the mean daily energy generation in a certain year (GWh/day), $P D E C$ is the percentage of days at energy capacity (\%), and $H E_{c}$ is the daily energy generation capacity (GWh/day). 
Annual hydro-energy generation $\left(H E_{A}\right)$ is the summation of hydro-energy generation in individual days in the year. The $F D E$ is the amount of hydro-energy generation that can be guaranteed on a daily basis throughout the year. Furthermore, the coefficient of variation of daily energy generation $\left(C V_{H E}\right)$ measures the dispersion in daily energy generation. Lastly, the percentage of days at energy capacity (PDEC) ranges from 0 to $100 \%$.

\section{1. 3. Pumping energy and water availability}

Pumping stations are widely used to extract and transfer water from rivers and reservoirs to higher elevations for treatment, distribution, or use. The amount of input energy required for water pumping depends primarily on three factors (Moreno et al., 2009, 2007; Tarjuelo et al., 2015). These factors are: (1) the elevation difference between the water abstraction and delivery points, (2) the amount of pumped water, and (3) the efficiencies of the pump and the motor. For pumping stations situated on river streams, the elevation of the water abstraction point increases with the river flow and vice versa depending on the river rating curve at the pumping location. Pumping from a storage reservoir to a higher elevation implies that the elevation of the water abstraction point equals the reservoir water level, which varies depending on the operating policy of the reservoir. The higher the elevation of the water abstraction point, the lower the pumping energy. The second factor that influences the pumping energy, i.e., the amount of pumped water, relies on the availability of sufficient water and the right to water abstraction. Generally, the amount of pumped water decreases when the river flow or reservoir storage water is less. Lastly, the overall efficiency of the pumping station also determines the amount of pumping energy. This efficiency depends on the elevation difference between the water abstraction and delivery points as well as the amount of pumped water. In the present study, four indicators were used to understand the interlinkages between water availability, i.e. river flow and reservoir storage, and water pumping. These indicators are annual pumping energy (Equation 6), lowest daily pumping 
energy (Equation 7), highest daily pumping energy (Equation 8), and variability in pumping energy (Equation 9).

For this study, the model was first extended to cover the Blue Nile Basin from the Ethiopian-

Sudanese border to Khartoum and the period from 1984 to 2016, and then was recalibrated and validated. The modified model was used to construct daily time series of hydropower generation, pumping energy, and reservoir evaporation and then to calculate the nexus indicators discussed in Section 3.1. 

this study. Fig. 4 shows a schematic of the model. The model includes eight inflow points, two hydropower dams, five irrigation schemes, four pumping stations, evaporation losses from the storage reservoirs, and channel losses. Daily river flow data for El-Diem Gage, ElHawata Gage, El-Gewisi Gage, and Sub-basins 1 to 5 were used together with the system operating rules to drive the model. It is worth mentioning that the inflow from sub-basins 1 to 5 was derived by Basheer et al. (2018) using a hydrological model driven by the African Rainfall Climatology Version 2 satellite rainfall data (Novella and Thiaw, 2013). As Fig.4 shows, the Lower Blue Nile model starts from El-Diem Gage, which is located near the

311 Ethiopian-Sudanese border. The outflow from El-Diem Gage and the inflow from sub-basins

3121 and 2 enter the Roseires Reservoir. After that, the outflow from the Roseires Reservoir 313 joins the inflow from sub-basins 3 and 4 before entering the Sennar Reservoir. Three 314 pumping stations abstract irrigation water directly from the Sennar reservoir to supply the 315 North West Sennar, the Suki, and the Rahad 1 schemes. Whereas the majority of the 316 irrigation water of the Rahad 1 Scheme comes from the Rahad River, the pumping station on the Blue Nile is operated only when the inflow of the Rahad River drops below the irrigation 318 demand of the Rahad 1 Scheme. The inflow from sub-basin 5 enters the Sennar Reservoir.

319 Headworks located on the left side of the Sennar Dam divert the irrigation water of the Gezira and the Managil by gravity. The outflow from the Sennar Dam joins the inflow from the

321 Dinder and the Rahad rivers, which originates in the Ethiopian Highlands. Flow data of the

322 Dinder and the Rahad rivers at El-Gewisi and El-Hawata gages were used to simulate the 323 flow of the two rivers, respectively. The combined flows of the Blue Nile, the Dinder River, and the Rahad River continue downstream before the Gunied Scheme abstracts its irrigation water using a pumping station. The remaining flow passes through El-Kamleen Gage, where the water level is derived using a rating curve, then combines with part of the return flow of 
the Gezira and the Managil before passing through the Khartoum Gage. The model also simulates hydropower generation, pumping energy, evaporation losses from reservoirs, and transmission losses from river reaches. Average monthly evaporation coefficients were used to simulate the evaporation losses from the Roseires and the Sennar reservoirs. A constant loss percentage and a constant lag time were populated for each river reach. Similarly, a constant percentage from irrigation water abstraction was used to estimate the return flows of the Rahad 1 and the Gezira and the Managil Schemes. For the four pumping stations, an average pumping efficiency was used in calculating the pumping energy for each station. The intake water levels of the pumping stations of the Rahad 1, the Suki, and the North West Sennar vary with the Sennar Reservoir water level. The water level at El-Kamleen Gage was connected to the intake water level of the Gunied pumping station.

\section{2. 2. Modeling framework}

To simulate water allocation and the associated hydrologic and hydraulic processes, a model was developed using RiverWare. Moreover, RiverWare was used to calculate the indicators and measures of the water-energy nexus. RiverWare is a generalized river basin modeling software that can simulate the water balance for several kinds of objects (e.g. storage dams, river reaches, and diversion structures) using a variety of approaches and temporal resolutions (Zagona et al., 2001). RiverWare is empowered with a policy language that enables adding prioritized system operating rules using logical statements. This particular attribute provides flexibility in modeling complex river systems. RiverWare has been recently used to model several complex river systems worldwide including the Nile (Basheer et al., 2019, 2018; Basheer and Elagib, 2018; Wheeler et al., 2018, 2016) and Colorado (United States of America and United Mexican States, 2012). 

validated from 2001 to 2016 . The calibration of the model was performed by adjusting the lag times of river reaches, channel loss percentages, and the return flow parameters of the Rahad

3541 and the Gezira and the Managil schemes. To assess the performance of the model, a comparison of the simulated and the available observed daily outflow from the Roseires Dam, outflow from the Sennar Dam, and flow at the Khartoum Gage was carried out. The recommendations of Stern et al. (2016), who provided performance rankings for daily models, were used to rate the performance of the Lower Blue Nile Basin model. Three model performance indicators were used, namely the coefficient of determination $\left(\mathrm{R}^{2}\right)$, the NashSutcliffe coefficient of efficiency (NSE), and the Mean Error Percentage (MEP),.

Fig. 5 shows the outflow from the Roseires and the Sennar dams and the flow at the

362 Khartoum Gage in the calibration and validation periods. Moreover, Table 2 shows the performance metrics (based on daily modeled and observed data) and the rankings of the model at the Roseires Dam, the Sennar Dam, and the Khartoum Gage. It is evident from Fig. 5 that the model could accurately capture the annual flow cycle at the three calibration and validation locations. Based on the recommendations of Stern et al. (2016) for daily models ranking, the model showed mostly excellent performances at the three locations in both the calibration and the validation periods (see Table 2). The exception is the performance at the

369 Khartoum Gage in the validation period using MEP, which showed a very good performance.

370 The high $\mathrm{R}^{2}$ values indicate that the model could explain a large portion of the observed values. All Pearson correlation coefficient $(\mathrm{R})$ values are significant at $\mathrm{p}<0.00001$. 


\section{Time series analysis}

The Standardized Streamflow Index (SSFI; Modarres, 2007) was used in this study to

375

376

377

378

379

380

381

382

383

384

385

386

387 analyze the temporal evolution of the annual river flow in terms of above (wet case) and below (drought case) the long-term average flow amount. SSFI was found suitable for this analysis due to the nearly normal distribution of the annual river flow explained by a low skewness coefficient of around -0.097 . To analyze the time series of the water-energy nexus indicators and measures, two statistical tests were performed. First, the shift in regime was detected by determining the change point(s) or year(s) in the time series with a statistically significant change in mean at the probability level, $\mathrm{p}$, according to the Student's t-test (Rodionov, 2004). The technique used herein uses the sequential algorithm, which requires less input data compared to other methods. Moreover, it has the ability to detect the regime shift earlier and subsequently monitor changes in its magnitude over time. For the current analysis, a cut-off length of 10 years and a significant level, p, of 0.05 , were chosen. The results of this analysis were then explained in the context of recognized hydrological phenomena in the basin, such as drought and flood, or human-induced changes in the river hydrology such as flow regulations. Next, the non-parametric Kendall-tau test with two-tailed (Kanji, 2006) was used to determine the significant trend direction over the regime (change) periods, i.e. before and/or after the change point. This analysis reveals whether there was a decreasing or increasing trend in the given flow time series.

\section{3. Data used}

The historic river flow records of the stream gages shown in Figs. 1 and 4 were acquired from the Ministry of Water Resources, Irrigation, and Electricity of Sudan (MoWRIES). The MoWRIES also provided the following data for the Sennar and the Roseires dams: the geometry of the reservoirs (i.e., the elevation-volume and elevation-area 
tables), the outlet capacities, the average monthly evaporation rates, and the turbines characteristics. An average pumping efficiency for the pumping stations in addition to the elevations of the discharge basins were obtained from MoIHES (1977). The water demands of the five irrigation schemes located in the study area were obtained from MoWRIES. The current operating policies for the Sennar and the Roseires dams in addition to the inflow from sub-basins 1 to 5 were obtained from Basheer et al. (2018). Table 3 outlines the operating rules of the Roseires and the Sennar dams before and after the heightening of the Roseires Dam. Key data are provided in the supplementary material.

\section{Results}

\section{1. Inter-annual variability of river flow}

408

Fig. 6 shows a time series of the SSFI of the Blue Nile flow at El-Diem Gage on an annual time scale. The figure clearly shows a decrease of successive below-average SSFIs over the study period following the persistent droughts of the 1980s, early 1990s, and early 2000s. These negative flow anomalies were primarily attributed to synchronized meteorological droughts reported in Sudan (Elagib and Elhag, 2011; Zhang et al., 2012) through analysis of 1964-2009 flow and rainfall data refuted consistent increasing or increasing trends in rainfall and flow extremes of recent years (Taye and Willems, 2012). It is noteworthy, however, that large-scale anomalies have been found to contribute to the flow anomalies of the Blue Nile (Abtew et al., 2009; Taye and Willems, 2012; Zaroug et al., 2014). The positive anomalies shown in Fig. 6 increase in frequency despite the dispersed negative anomalies of the early $20^{\text {th }}$ century. Intensive land use and land cover change, as well as increasing rainfall extremes in the Upper Blue Nile in Ethiopia, could be suggested to have caused the recent positive flow anomalies (Degefu and Bewket, 2014; Tekleab et al., 
2013; Woldesenbet et al., 2017; Worku et al., 2018). Table 4 indicates a significant regime

shift in the raw flow data in the year 2006 when the mean escalated from 47,330 to 55,938

$\mathrm{Mm}^{3} /$ year. Accordingly, a positive trend occurred from 1984-2005 but not significant at $\mathrm{p}=$ 0.05 ; the significance level was found to be 0.085 .

\section{2. Water-energy productivity}

Fig. 7 depicts a time series of the combined WEP of the Roseires and the Sennar dams.

The WEP shows high year-to-year variability during the decade 2002-2012 and a drop thereafter to its lowest value, which almost remained since 2013. As shown in Table 4, the year 2013 represented the year of change in regime in the WEP time series; however, no significant trend was found during this period. Before 2013, the ranges of hydro-energy generation and the reservoir evaporation were 1450-1980 GWh/year and 540-895 $\mathrm{Mm}^{3} /$ year, respectively. Thereafter, these ranges became approximately $2275-2410 \mathrm{GWh} /$ year and 1250 $1330 \mathrm{Mm}^{3} /$ year, respectively. Although both the hydro-energy generation and the reservoir evaporation increased, the WEP dropped due to a higher rate of increase in evaporation compared to that in hydro-energy generation.

\section{3. Nexus indicators of hydro-energy generation}

In Fig. 8a, the time series of both the annual energy and the number of days at installed capacity are increasing; however, two changes in regime, i.e. in 1996 and 2013, were detected for the former but only one in 2013 for the latter as indicated in Table 4. The annual energy shows an increased mean from 1,612 to 1,784 GWh and an increasing trend over the

441 period 1984-1995 (Table 4); then, the mean increased once again to 2,353 GWh, but the trend

442 was not significant during this regime. The regime shift in annual energy in 1996 can be explained by an increase in energy generation due to an increase in river flow during the dry 
was around 7,300 $\mathrm{Mm}^{3}$ compared to approximately 10,080 $\mathrm{Mm}^{3}$ from 1996 to 2012.

446 Accordingly, the mean energy generation in the dry season grew from around $754 \mathrm{GWh}$

447 before 1996 to over 915 GWh from 1996 to 2012. In 2013, the percentage of days of the year

448 recording installed energy capacity increased significantly from $\sim 39$ to $\sim 61 \%$ with a

449 significant increasing trend during 1984-2012. During 1984-2016, the firm energy exhibited

450 an increasing trend over several cycles but without a regime shift. Fig. $8 \mathrm{~b}$ and Table 4 show

451 increasing variability of the daily energy over time which escalated too high after 2012 to

452 display a change in regime.

\section{4. Nexus indicators of pumping energy}

454

455

456

457

458

459

460

461

462

463

464

465

466

467

468

As regards the pumping energy indicators, a prominent remark to make is the non-existence of significant trend in any one of them despite the occurrence of regime shifts. It can be noticed in Fig. 9a that the annual pumping energy had a regime shift in 2012 when the mean dropped from 3.84 to $3.30 \mathrm{GWh} /$ year. The highest daily pumping energy has maintained somewhat a constant level (Fig. 9b). On the other hand, the lowest daily pumping energy reveals significant regime shift in 2014 characterized by a decline in the mean for the period of 2014 onwards in comparison with the mean for the period 1984-2013. Here, a rise occurred in the former indicator while a drop was detected in the time series of the latter indicator. Over the study period, two changes occurred in the time series of the coefficient of variability of the daily pumping energy, one detected in 2003 while the other in 2014 (Table

4). The former seems to correspond to a prolonged drought (below-average flow) period that extended from 2002 to 2005, as shown in Fig. 6.

\section{Discussion}

It is important to decipher the reason behind the striking change in regime in 2013 for most of the indicators discussed above. The Roseires Dam was heightened by the hydrologic 
year 2012/2013, causing noticeable hydrological alterations (Alrajoula et al., 2016). The dam was initially constructed with a Full Supply Level (FSL) of $480 \mathrm{~m}$ asl with the possibility to be raised to 490 m asl (MoIHPS, 1966; Roseires Dam Heightening Unit, 2005). The Roseires was heightened to meet the increasing demands for electricity and irrigation water and to compensate for the storage capacity that had been lost to sedimentation (Ahmed and Ismail, 2008). Heightening the Roseires Dam raised the maximum storage capacity from about 1,700 to $5,909 \mathrm{Mm}^{3}$ and the maximum reservoir surface area from roughly 260 to $565 \mathrm{~km}^{2}$. To comprehend the implications of the heightening of the Roseires Dam for the nexus indicators discussed above, one must first understand the operating rules of the Sennar and the Roseires Dams. Both dams were constructed for seasonal storage, i.e. to store water in the flood season to be used in the dry season for irrigation water supply and hydropower generation. Four successive stages characterize the seasonal operation of the Roseires and the Sennar Dams: (1) impoundment, (2) stabilization at FSL, (3) draw-down, and (4) stabilization at Minimum Operating Level (MOL). The following information on the four operation stages was acquired from MoIHPS (1968) and Basheer et al. (2018). In the first stage, the water levels of the two reservoirs are raised from MOL to FSL. Before the heightening of the Roseires Dam, the first stage used to start on a day from 1st to 26th of September and continue for 45 days for both dams. The start day of the first stage has been changed to between 11th of August and 11th of September for both dams, and the impoundment period has been amended for the Roseires Dam to 55 days. Before (after) the heightening of the Roseires Dam, the start day of the first stage used to be (is) determined based on the following criteria: 1st of September 490 (11th of August) if the flow at El-Diem Gage is less than $350 \mathrm{Mm}^{3} / \mathrm{day}$ ( $450 \mathrm{Mm}^{3} / \mathrm{day}$ ) by that day; a day between 1st of September (11th of August) and 26th of September (11th of

492 September) when the flow at El-Diem Gage drops below $350 \mathrm{Mm}^{3} /$ day $\left(450 \mathrm{Mm}^{3} /\right.$ day); 26th of September (11th of September) if the flow at El-Diem Gage remains higher than 350 
$494 \mathrm{Mm}^{3} /$ day (450 $\mathrm{Mm}^{3} /$ day) by that day. The second operation stage, i.e. stabilization at FSL, starts after the end of the first stage and continues until the river flow drops below the water demands. In the third stage, the water stored in the Roseires and the Sennar reservoirs is

497 drawn down to provide the difference between the river flow and various water demands

498 whenever possible. Lastly, the fourth stage starts at the end of May to maintain the water

499 levels of the two reservoirs at MOL and continues until the start of the first stage. The

500 purpose of the fourth stage is to minimize reservoir sedimentation during the peak flood 501 period.

The 2013 regime change in annual energy generation (Table 4 and Fig. 8a) was due to the increase in energy generation from the Roseires Dam during the first, second, and third stages of the seasonal operation of the dam. This increase in energy generation was due to the increase in reservoir water levels and outflows. However, the rise in water levels increased the reservoir surface area, escalated reservoir evaporation, and reduced the WEP (Fig. 7). The

507 increase in the number of days at energy capacity can be explained by the increase in

508 reservoir water levels and water releases from the Roseires Dam after the heightening.

509 Further investigation of this result shows that when the turbines of the Roseires Dam reach their power capacity (280 MW; Table 1), water releases are made through the other outlets of

511 the dam, i.e. gated spillways and deep sluice gates. These observations indicates the power

512 capacity of the turbines of the Roseires Dam could be raised to utilize the hydropower

513 potential that the heightening has created. Furthermore, the Roseires heightening has increased the variability in daily energy generation and has stabilized the firm daily energy generation (Fig. 8b). As explained in Section 2, four schemes in the study area abstract their

516 irrigation water via pumping. Three of them abstract directly from the Sennar Reservoir while 517 one abstracts from the river channel upstream from Khartoum (see Fig. 4). The 2012 shift in 518 annual pumping energy can be attributed to the modification made to the start of the first 
519 stage of the seasonal operation of Sennar Dam that was introduced with the heightening of

520 Roseires Dam. This modification results in earlier filling of the Sennar Reservoir, higher

521 reservoir water levels, and less annual pumping energy. On the other hand, the shifts in the

522 highest daily pumping energy, the lowest daily pumping energy, and the variability in

523 pumping energy are due to an interplay of the inter-annual variability of river flow and dam

524 operating rules. The present analysis of regime shift in water-energy nexus indicators shows

525 the ability to detect significant human interventions in the hydrological system such as the

526 heightening of the Roseires Dam in 2013.

527 6. Conclusions

In this study, the Blue Nile - a major tributary of the Nile - within Sudan was taken to demonstrate the usefulness of temporal analysis of the nine nexus indicators. A calibrated and validated daily water balance model of the study region has been utilized to construct time series for the nine water-energy nexus indicators from 1984 to 2016 . Time series analysis has been performed to understand and interpret the temporal dynamics of the nine indicators in terms of regime shifts and trends.

The nine indicators of water-energy nexus that have been explored in this study for hydropower generation and water pumping can help understand the interplay of hydroenergy, pumping energy, reservoir evaporation, and water availability. Such an understanding could contribute towards efficient utilization of the water and energy resources (Liu et al.,

538 2017)m especially under the ongoing campaigns to better operate existing water-related infrastructures rather than building new ones (Chen et al., 2016). of days at energy capacity, CV of daily energy generation, WEP, and annual pumping energy in 2012/2013. These shifts were due to the heightening of the Roseires Dam by $10 \mathrm{~m}$. Even 
543 though the heightening increased annual energy generation, it reduced the WEP due to a

544 considerable increase in evaporation losses. It is noteworthy that the hydropower capacity of

545 the Roseires turbines has not been increased following the heightening of the dam. The

546 significant shift in the percentage of days at energy capacity in 2013 indicates that

547 hydropower turbines of higher capacity could be installed in the Roseires Dam to utilize its

548 hydropower potential fully. The regime shifts detected in 2012/2013 shows that the use of

549 statistical regime shift analysis of hydrological time series is robust enough to detect human

550 interferences in the hydrology of rivers such as dam construction. This robustness could

551 prove useful in identifying not only interventions in a river system in terms of infrastructural

552 development, but also changes in the operation of existing water infrastructures which are

553 often inadequately documented. Such an analysis could help in highlighting the untapped

554 efficiency gains in water and energy systems (e.g. possible increase of turbines capacity).

The nexus indicators of hydropower generation and water pumping that have been analyzed in this study are not claimed to be comprehensive; rather, they represent a valuable step toward addressing the water-energy nexus in similar cases of dammed river basins. The presented nexus indicators can also be tailored depending on the analyzed case and analysis 559 purpose.

\section{References}

Abtew, W., Melesse, A.M., Dessalegne, T., 2009. El Niño Southern Oscillation link to the Blue Nile River Basin hydrology. Hydrological Processes 23, 3653-3660. https://doi.org/10.1002/hyp.7367

Ackerman, F., Fisher, J., 2013. Is there a water-energy nexus in electricity generation? Longterm scenarios for the western United States. Energy Policy 59, 235-241. https://doi.org/10.1016/j.enpol.2013.03.027 
International Sediment Initiative. Khartoum.

569

570

571

572

573

574

575

576

577

578

579

580

581

582

583

584

585

586

587

588

589

590

591

592

Al-Saidi, M., Elagib, N., 2017. Towards understanding the integrative approach of the water, energy and food nexus. Science of the Total Environment 574, 1131-1139. https://doi.org/10.1016/j.scitotenv.2016.09.046

Al-Saidi, M., Hefny, A., 2018. Institutional arrangements for beneficial regional cooperation on water, energy and food Priority Issues in the Eastern Nile Basin. Journal of Hydrology 562, 821-831. https://doi.org/10.1016/j.jhydrol.2018.05.009

Alrajoula, M.T., Al Zayed, I.S., Elagib, N.A., Hamdi, M.R., 2016. Hydrological, socio-economic and reservoir alterations of Er Roseires Dam in Sudan. Science of the Total Environment 566-567, 938-948. https://doi.org/10.1016/j.scitotenv.2016.05.029

Bakken, T.H., Killingtveit, Å., Alfredsen, K., 2017. The water footprint of hydropower production-State of the art and methodological challenges. Global Challenges 1 , 1600018. https://doi.org/10.1002/gch2.201600018

Basheer, M., Elagib, N.A., 2018. Sensitivity of water-energy nexus to dam operation: A water-energy productivity concept. Science of the Total Environment 616-617, 918926. https://doi.org/10.1016/j.scitotenv.2017.10.228

Basheer, M., Sulieman, R., Ribbe, L., 2019. Exploring management approaches for water and energy in the data-scarce Tekeze-Atbara Basin under hydrologic uncertainty. International Journal of Water Resources Development 1-26. https://doi.org/10.1080/07900627.2019.1591941

Basheer, M., Wheeler, K.G., Ribbe, L., Majdalawi, M., Abdo, G., Zagona, E.A., 2018. Quantifying and evaluating the impacts of cooperation in transboundary river basins on the water-energy-food nexus: The Blue Nile Basin. Science of the Total Environment 630, 1309-1323. https://doi.org/10.1016/j.scitotenv.2018.02.249

Bazilian, M., Rogner, H., Howells, M., Hermann, S., Arent, D., Gielen, D., Komor, P., Steduto, P., Mueller, A., Tol, R., Yumkella, K., 2011. Considering the energy, water and food nexus: Towards an integrated modelling approach. Energy Policy 39, 7896-7906. https://doi.org/10.1016/j.enpol.2011.09.039 
596

597

598

599

600

601

602

603

604

605

606

607

608

609

610

611

612

613

614

615

616

617

618

619

620

621

622

623

Chen, J., Shi, H., Sivakumar, B., Peart, M., 2016. Population, water, food, energy and Dams. Renewable and Sustainable Energy Reviews 56, 18-28. https://doi.org/10.1016/j.rser.2015.11.043

Conway, D., 2017. Water resources: Future Nile river flows. Nature Climate Change 7, 319320. https://doi.org/10.1038/nclimate3285

Conway, D., Hulme, M., 1993. Recent fluctuations in precipitation and runoff over the Nile sub-basins and their impact on main Nile discharge. Climatic Change 25, 127-151. https://doi.org/10.1007/BF01661202

Dai, J., Wu, S., Han, G., Weinberg, J., Xie, X., Wu, X., Song, X., Jia, B., Xue, W., Yang, Q., 2018. Water-energy nexus: A review of methods and tools for macro-assessment. Applied Energy 210, 393-408. https://doi.org/10.1016/j.apenergy.2017.08.243

Davies, H.R.J., Walsh, R.P.D., 1997. Historical changes in the flood hazard at Khartoum, Sudan: Lessons and warnings for the future. Singapore Journal of Tropical Geography 18, 123-140. https://doi.org/10.1111/1467-9493.00012

Degefu, M.A., Bewket, W., 2014. Variability and trends in rainfall amount and extreme event indices in the Omo-Ghibe River Basin, Ethiopia. Regional Environmental Change 14, 799-810. https://doi.org/10.1007/s10113-013-0538-z

DIU, 2016. Roseires heightening project [WWW Document]. Ministry of Water Resources and Electricity of Sudan. URL http://www.roseiresdam.gov.sd/en/raising_project.htm (accessed 27 January 2019).

El Gafy, I., Grigg, N., Reagan, W., 2017. Water-food-energy nexus index to maximize the economic water and energy productivity in an optimal cropping pattern. Water International 42, 495-503. https://doi.org/10.1080/02508060.2017.1309630

Elagib, N.A., Elhag, M.M., 2011. Major climate indicators of ongoing drought in Sudan. Journal of Hydrology 409, 612-625. https://doi.org/10.1016/j.jhydrol.2011.08.047

Elagib, N.A., Saad, S.A.Gayoum, Basheer, M., Rahma, A.E., Gore, E.D.L., 2019. Exploring the urban water-energy-food nexus under environmental hazards within the Nile. Stochastic Environmental Research and Risk Assessment. 
Endo, A., Tsurita, I., Burnett, K., Orencio, P.M., 2017. A review of the current state of research on the water, energy, and food nexus. Journal of Hydrology: Regional Studies 11, 20-30. https://doi.org/10.1016/j.ejrh.2015.11.010

Engström, R.E., Howells, M., Destouni, G., Bhatt, V., Bazilian, M., Rogner, H.H., 2017. Connecting the resource nexus to basic urban service provision - with a focus on water-energy interactions in New York City. Sustainable Cities and Society 31, 83-94. https://doi.org/10.1016/j.scs.2017.02.007

Flammini, A., Puri, M., Pluschke, L., Dubois, O., 2014. Walking the nexus talk: Assessing the water-energy-food nexus in the context of the sustainable energy for all initiative (No. 58), Environment and Natural Resources Working Paper. Rome.

Gleick, P.H., 1994. Water and energy. Annual review of energy and the environment 19, 267-299. https://doi.org/10.1146/annurev.eg.19.110194.001411

Goor, Q., Halleux, C., Mohamed, Y., Tilmant, A., 2010. Optimal operation of a multipurpose multireservoir system in the Eastern Nile River Basin. Hydrology and Earth System Sciences 14, 1895-1908. https://doi.org/10.5194/hess-14-1895-2010

Hamududu, B., Killingtveit, A., 2012. Assessing climate change impacts on global hydropower. Energies 5, 305-322. https://doi.org/10.3390/en5020305

Helmstedt, K.J., Stokes-Draut, J.R., Larsen, A.E., Potts, M.D., 2018. Innovating at the food, water, and energy interface. Journal of Environmental Management 209, 17-22. https://doi.org/10.1016/j.jenvman.2017.12.026

Howells, M., Hermann, S., Welsch, M., Bazilian, M., Segerström, R., Alfstad, T., Gielen, D., Rogner, H., Fischer, G., van Velthuizen, H., Wiberg, D., Young, C., Roehrl, R., Mueller, A., Steduto, P., Ramma, I., 2013. Integrated analysis of climate change, land-use, energy and water strategies. Nature Climate Change 3, 621-626. https://doi.org/10.1038/nclimate1789

Hu, M.C., Huang, T., Yu, H.L., Tung, C.P., 2018. Stochastic competitive analysis of hydropower and water supplies within an energy-water nexus. Stochastic 
652

653

654

655

656

657

658

659

660

661

662

663

664

665

666

667

668

669

670

671

672

673

674

675

676

677

678

679

680

Jalilov, S., Keskinen, M., Varis, O., Amer, S., Ward, F., 2016. Managing the water-energy-food nexus: Gains and losses from new water development in Amu Darya River Basin. Journal of Hydrology 539, 648-661. https://doi.org/10.1016/j.jhydrol.2016.05.071

Kanji, G., 2006. 100 Statistical tests. 3rd edn. SAGE Publications

Ltd, London, California, New Delhi, https://doi.org/10.1007/s11012-012-9654-y

Keskinen, M., Guillaume, J., Kattelus, M., Porkka, M., Räsänen, T., Varis, O., 2016. The waterenergy-food nexus and the transboundary context: Insights from rarge Asian rivers. Water 8. https://doi.org/10.3390/w8050193

Keskinen, M., Someth, P., Salmivaara, A., Kummu, M., 2015. water-energy-food nexus in a transboundary river basin: The case of Tonle Sap Lake, Mekong River Basin. Water 7, 5416-5436. https://doi.org/10.3390/w7105416

Kibaroglu, A., Gürsoy, S., 2015. Water-energy-food nexus in a transboundary context: the Euphrates-Tigris river basin as a case study. Water International 40, 824-838. https://doi.org/10.1080/02508060.2015.1078577

Larsen, M.A.D., Drews, M., 2019. Water use in electricity generation for water-energy nexus analyses: The European case. Science of the Total Environment 651, 2044-2058. https://doi.org/10.1016/j.scitotenv.2018.10.045

Lawford, R., Bogardi, J., Marx, S., Jain, S., Wostl, C.P., Knüppe, K., Ringler, C., Lansigan, F., Meza, F., 2013. Basin perspectives on the water-energy-food security nexus. Current Opinion in Environmental Sustainability 5, 607-616. https://doi.org/10.1016/j.cosust.2013.11.005

Lawford, R.G., 2019. A design for a data and information service to address the knowledge needs of the water-energy-food (W-E-F) nexus and strategies to facilitate its implementation. Frontiers in Environmental Science 7. https://doi.org/10.3389/fenvs.2019.00056

Lebel, L., Lebel, B., 2018. Nexus narratives and resource insecurities in the Mekong Region. Environmental Science and Policy 90, 164-172. 
682

683

684

685

686

687

688

689

690

691

692

693

694

695

696

697

698

699

700

701

702

703

704

705

706

707

708

Liu, D., Guo, S., Liu, P., Xiong, L., Zou, H., Tian, J., Zeng, Y., Shen, Y., Zhang, J., 2019. Optimisation of water-energy nexus based on its diagram in cascade reservoir system. Journal of Hydrology 569, 347-358. https://doi.org/10.1016/j.jhydrol.2018.12.010

Liu, J., Yang, H., Cudennec, C., Gain, A.K., Hoff, H., Lawford, R., Qi, J., de Strasser, L., Yillia, P.T., Zheng, C., 2017. Challenges in operationalizing the water-energy-food nexus. Hydrological Sciences Journal 62, 1714-1720. https://doi.org/10.1080/02626667.2017.1353695

Modarres, R., 2007. Streamflow drought time series forecasting. Stochastic Environmental Research and Risk Assessment 21, 223-233. https://doi.org/10.1007/s00477-006-00581

MolHES, 1977. Blue Nile Waters Study Phase IA: Availability and use of Blue Nile Water. Khartoum.

MolHPS, 1968. Regulation Rules for the Working of the Reservoirs at Roseires and Sennar on the Blue Nile.

MolHPS, 1966. Roseires Dam. Khartoum.

Moreno, M.A., Carrión, P.A., Planells, P., Ortega, J.F., Tarjuelo, J.M., 2007. Measurement and improvement of the energy efficiency at pumping stations. Biosystems Engineering 98, 479-486. https://doi.org/10.1016/j.biosystemseng.2007.09.005

Moreno, M.A., Planells, P., Córcoles, J.I., Tarjuelo, J.M., Carrión, P.A., 2009. Development of a new methodology to obtain the characteristic pump curves that minimize the total cost at pumping stations. Biosystems Engineering 102, 95-105. https://doi.org/10.1016/j.biosystemseng.2008.09.024

Nawab, A., Liu, G., Meng, F., Hao, Y., Zhang, Y., 2019. Urban energy-water nexus: Spatial and inter-sectoral analysis in a multi-scale economy. Ecological Modelling 403, 44-56. https://doi.org/10.1016/j.ecolmodel.2019.04.020

NBI, 2012. State of the River Nile Basin. Entebbe.

Nilsson, C., Reidy, C.A., Dynesius, M., Revenga, C., 2005. Fragmentation and flow regulation 
of the world's large river systems. Science 308, 405-408.

711

712

713

714

715

716

717

718

719

720

721

722

723

724

725

726

727

728

729

730

731

732

733

734

Novella, N., Thiaw, W., 2013. African rainfall climatology version 2 for famine early warning systems. Journal of Applied Meteorology and Climatology 52, 588-606. https://doi.org/10.1175/JAMC-D-11-0238.1

Omer, A.Y.A., Ali, Y.S.A., Roelvink, J.A., Dastgheib, A., Paron, P., Crosato, A., 2015. Modelling of sedimentation processes inside Roseires Reservoir (Sudan). Earth Surface Dynamics 3, 223-238. https://doi.org/10.5194/esurf-3-223-2015

Perry, C., 2011. Accounting for water use: Terminology and implications for saving water and increasing production. Agricultural Water Management 98, 1840-1846. https://doi.org/https://doi.org/10.1016/j.agwat.2010.10.002

Pittock, J., Dumaresq, D., Bassi, A., 2016. Modeling the hydropower-food nexus in large river basins: A Mekong case study. Water 8. https://doi.org/10.3390/w8100425

Rasul, G., 2014. Food, water, and energy security in South Asia: A nexus perspective from the Hindu Kush Himalayan region. Environmental Science and Policy 39, 35-48. https://doi.org/10.1016/j.envsci.2014.01.010

Rasul, G., Neupane, N., Hussain, A., Pasakhala, B., 2019. Beyond hydropower: towards an integrated solution for water, energy and food security in South Asia. International Journal of Water Resources Development. https://doi.org/10.1080/07900627.2019.1579705

Rodionov, S.N., 2004. A sequential algorithm for testing climate regime shifts. Geophysical Research Letters 31, 2-5. https://doi.org/10.1029/2004GL019448

Romero-Lankao, P., Bruns, A., Wiegleb, V., 2018. From risk to WEF security in the city: the influence of interdependent infrastructural systems. Environmental Science and Policy 90, 213-222. https://doi.org/10.1016/j.envsci.2018.01.004

Roseires Dam Heightening Unit, 2005. Updating economic and financial viability Study of Dam Heightening. Khartoum.

Sadoff, C.W., Grey, D., 2002. Beyond the river: the benefits of cooperation on international 
rivers. Water Policy 4, 389-403. https://doi.org/https://doi.org/10.1016/S13667017(02)00035-1

Shi, H., Chen, J., Liu, S., Sivakumar, B., 2019. The Role of Large Dams in Promoting Economic Development under the Pressure of Population Growth. Sustainability 11. https://doi.org/10.3390/su11102965

Si, Y., Li, X., Yin, D., Li, T., Cai, X., Wei, J., Wang, G., 2019. Revealing the water-energy-food nexus in the Upper Yellow River Basin through multi-objective optimization for reservoir system. Science of the Total Environment 682, 1-18. https://doi.org/10.1016/j.scitotenv.2019.04.427

Simpson, G.B., Jewitt, G.P.W., 2019. The Development of the water-energy-food nexus as a framework for achieving resource security: A review. Frontiers in Environmental Science 7. https://doi.org/10.3389/fenvs.2019.00008

Stern, M., Flint, L., Minear, J., Flint, A., Wright, S., 2016. Characterizing changes in streamflow and sediment supply in the Sacramento River Basin, California, using hydrological simulation program-FORTRAN (HSPF). Water 432, 1-21. https://doi.org/10.3390/w8100432

Sutcliffe, J., Parks, Y., 1999. The hydrology of the Nile, International Association of Hydrological Sciences. The International Association of Hydrological Science, Wallingford.

Sutcliffe, J. V., Dugdale, G., Milford, J.R., 1989. The sudan floods of 1988. Hydrological Sciences Journal 34, 355-364. https://doi.org/10.1080/02626668909491339

Tarjuelo, J.M., Rodriguez-Diaz, J.A., Abadía, R., Camacho, E., Rocamora, C., Moreno, M.A., 2015. Efficient water and energy use in irrigation modernization: Lessons from Spanish case studies. Agricultural Water Management 162, 67-77. https://doi.org/10.1016/j.agwat.2015.08.009

Taye, M.T., Willems, P., 2012. Temporal variability of hydroclimatic extremes in the Blue Nile basin. Water Resources Research 48, 1-13. https://doi.org/10.1029/2011WR011466

Tekleab, S., Mohamed, Y., Uhlenbrook, S., Wenninger, J., 2013. Hydrologic responses to land 
cover change: the case of Jedeb mesoscale catchment, Abay/Upper Blue Nile basin, Ethiopia. Hydrological Processes 28, 5149-5161. https://doi.org/10.1002/hyp.9998

United States of America and United Mexican States, 2012. Minute 319 of the utilization of waters of the Colorado and Jijuana rivers and of the Rio Grande, treaty between the United States of America and Mexico. Washington, D.C.

Van Vliet, M.T.H., Wiberg, D., Leduc, S., Riahi, K., 2016. Power-generation system vulnerability and adaptation to changes in climate and water resources. Nature Climate Change 6, 375-380. https://doi.org/10.1038/nclimate2903

Wheeler, K., Hall, J., Abdo, G., Dadson, S., Kasprzyk, J., Smith, R., Zagona, E., 2018. Exploring cooperative transboundary river management dtrategies for the Eastern Nile Basin. Water Resources Research 9224-9254. https://doi.org/10.1029/2017WR022149

Wheeler, K.G., Basheer, M., Mekonnen, Z., Eltoum, S., Mersha, A., Abdo, G., Zagona, E., Hall, J., Dadson, S., 2016. Cooperative filling approaches for the Grand Ethiopian Renaissance Dam. Water International 8060, 1-24. https://doi.org/10.1080/02508060.2016.1177698

Woldesenbet, T.A., Elagib, N.A., Ribbe, L., Heinrich, J., 2017. Hydrological responses to land use/cover changes in the source region of the Upper Blue Nile Basin, Ethiopia. Science of the Total Environment 575, 724-741.

https://doi.org/10.1016/j.scitotenv.2016.09.124

Worku, G., Teferi, E., Bantider, A., Dile, Y.T., 2018. Observed changes in extremes of daily rainfall and temperature in Jemma Sub-Basin, Upper Blue Nile Basin, Ethiopia. Theoretical and Applied Climatology. https://doi.org/10.1007/s00704-018-2412-x

Zagona, E., Fulp, T., Shane, R., Magee, T., Goranflo, H.M., 2001. Riverware: a generalized tool for complex reservoir system modeling. Journal of the American Water Resources Association 37, 913-929.

Zaroug, M.A.H., Eltahir, E.A.B., Giorgi, F., 2014. Droughts and floods over the upper catchment of the Blue Nile and their connections to the timing of El Niño and la Niña events. Hydrology and Earth System Sciences 18, 1239-1249. https://doi.org/10.5194/hess-18-1239-2014 
794 Zhang, X., Vesselinov, V. V., 2016. Energy-water nexus: Balancing the tradeoffs between 795 two-level decision makers. Applied Energy 183, 77-87.

796 https://doi.org/10.1016/j.apenergy.2016.08.156

797 Zhang, Z., Xu, C.-Y., Yong, B., Hu, J., Sun, Z., 2012. Understanding the changing

798 characteristics of droughts in Sudan and the corresponding components of the

799 hydrologic cycle. Journal of Hydrometeorology 13, 1520-1535.

$800 \quad$ https://doi.org/10.1175/JHM-D-11-0109.1

801 


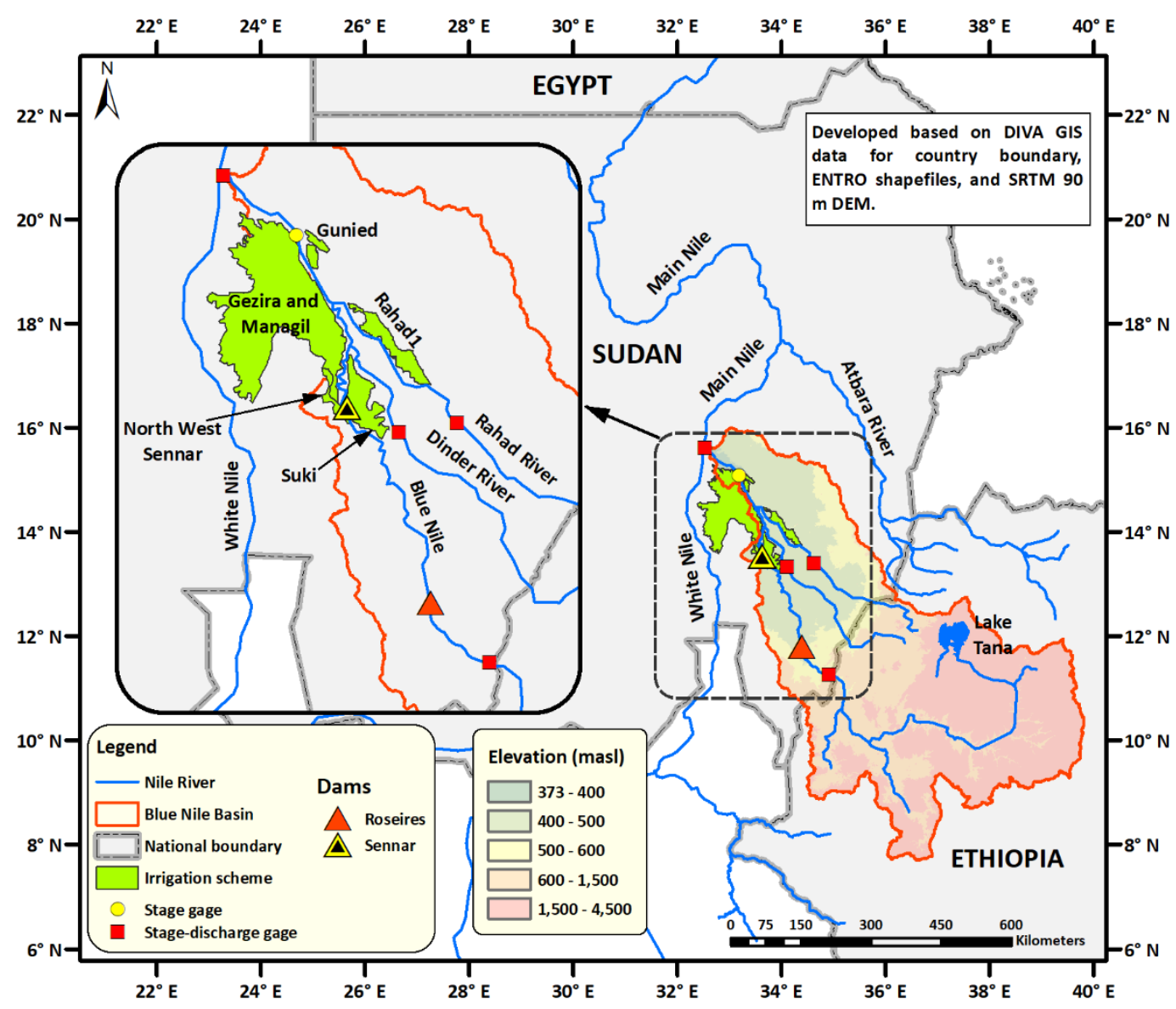

Fig. 1 Main features of the Lower Blue Nile Basin.

Note: GIS = Geographic Information System; ENTRO = Eastern Nile Technical Regional Office; SRTM = Shuttle Radar Topography Mission; DEM = Digital Elevation Model 

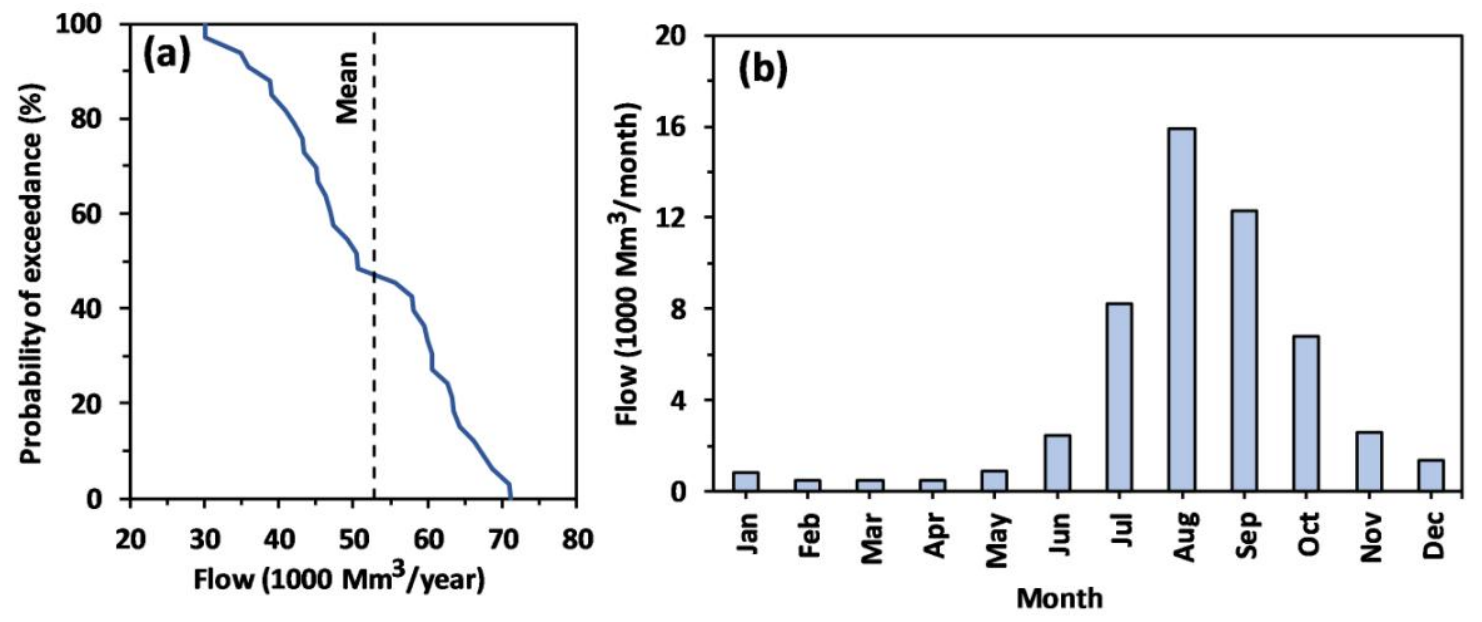

Fig. 2 Total flow of the Blue Nile at the outlet of the basin from 1984 to 2016: (a) exceedance probability of the annual flow (b) mean monthly flow.

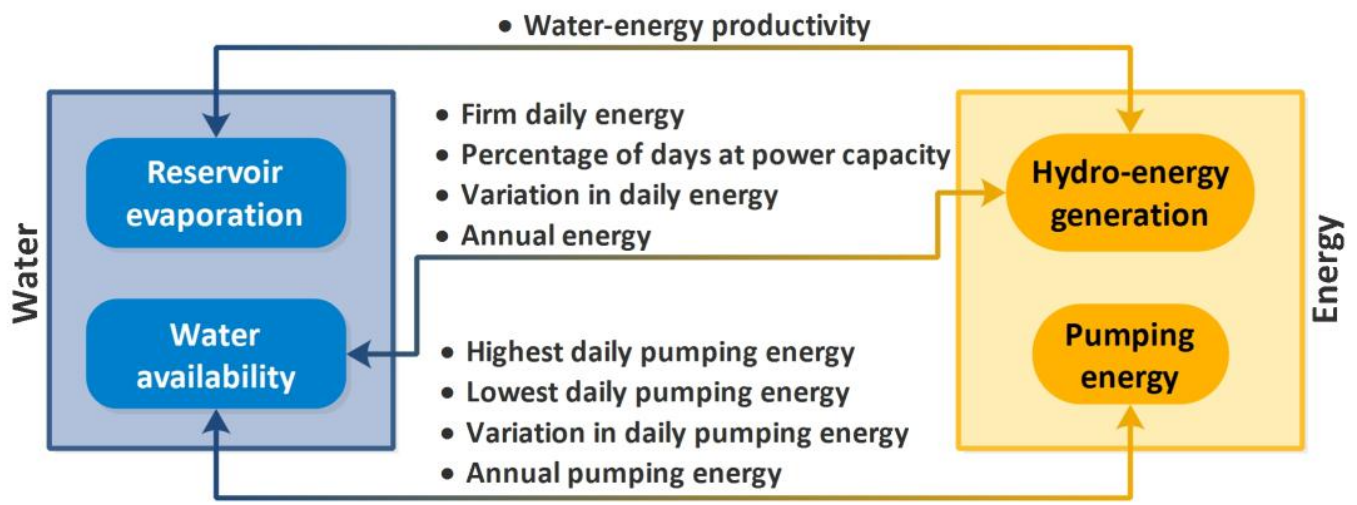

Fig. 3 Water-energy nexus indicators and measures in the context of hydropower generation and water pumping 


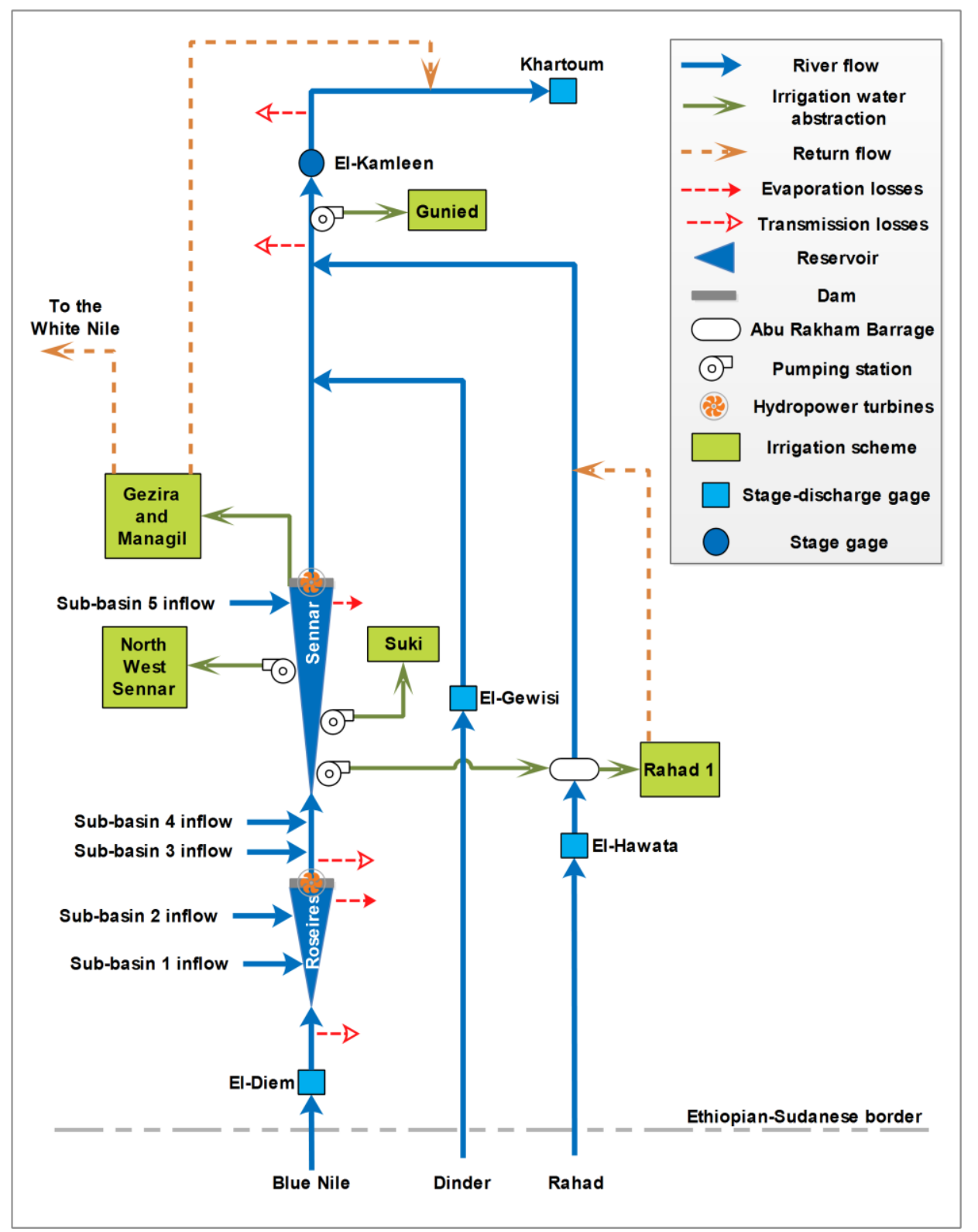

Fig. 4 Schematic of the model of the Lower Blue Nile Basin 

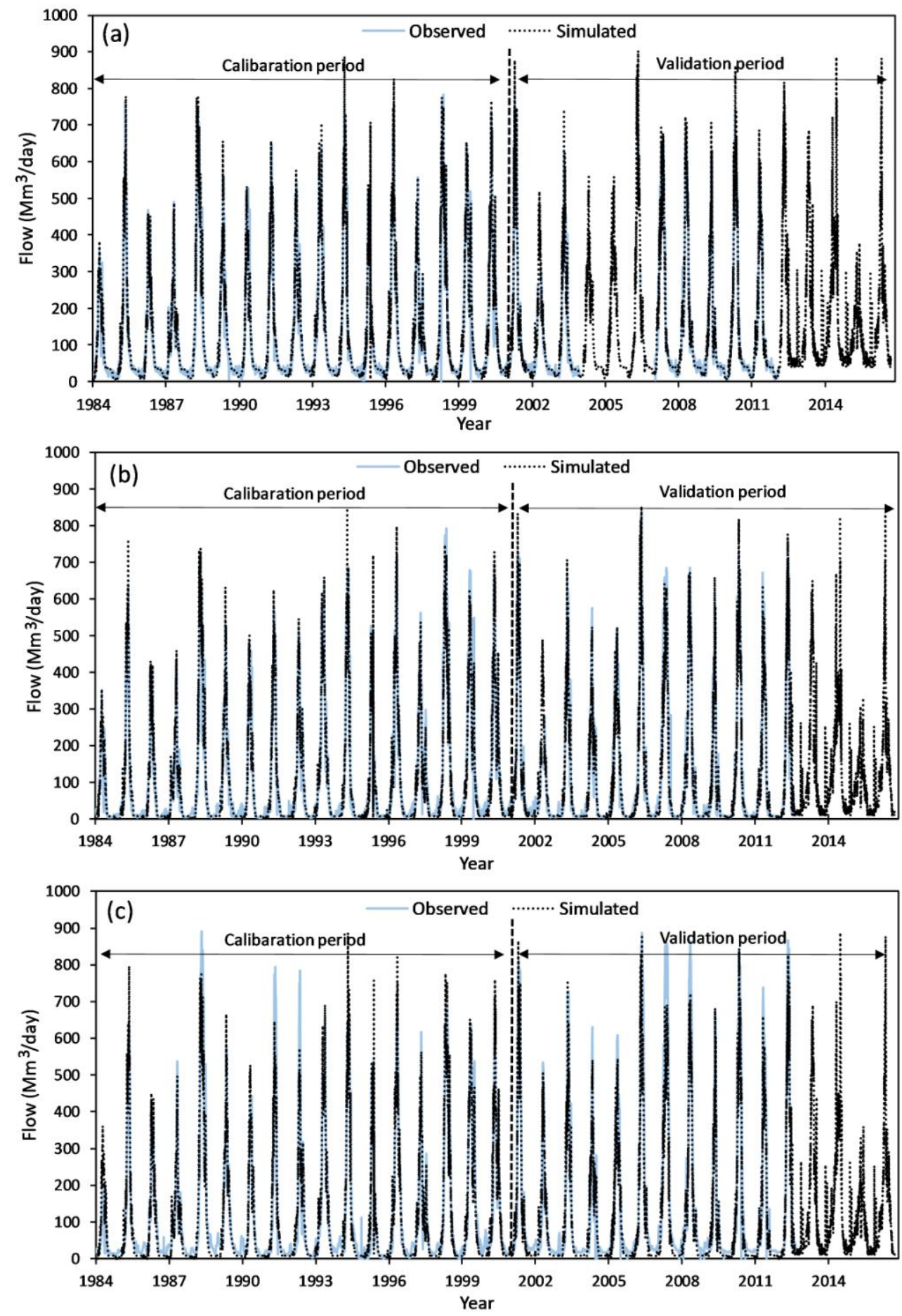

Fig. 5 Observed and simulated outflow from: (a) the Roseires Dam, (b) the Sennar Dam, and (c) the Khartoum Gage 


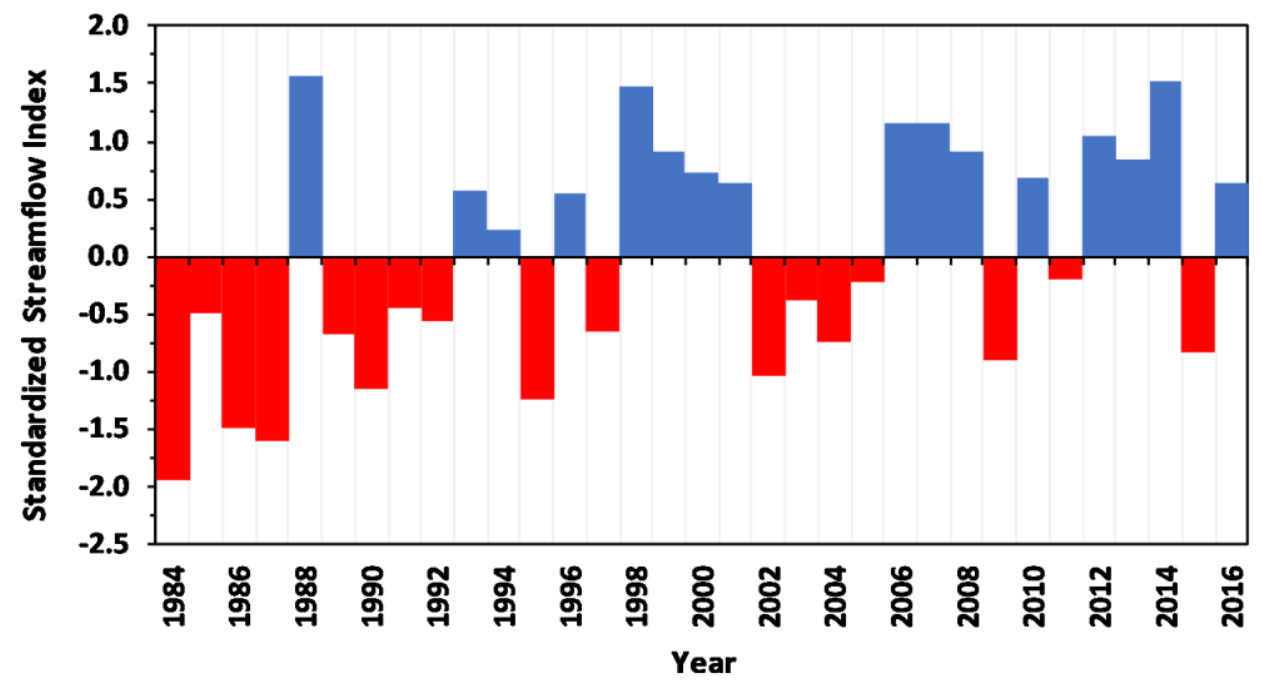

Fig. 6 Annual Standardized Streamflow Index (SSI) of the Blue Nile at El-Diem Gage

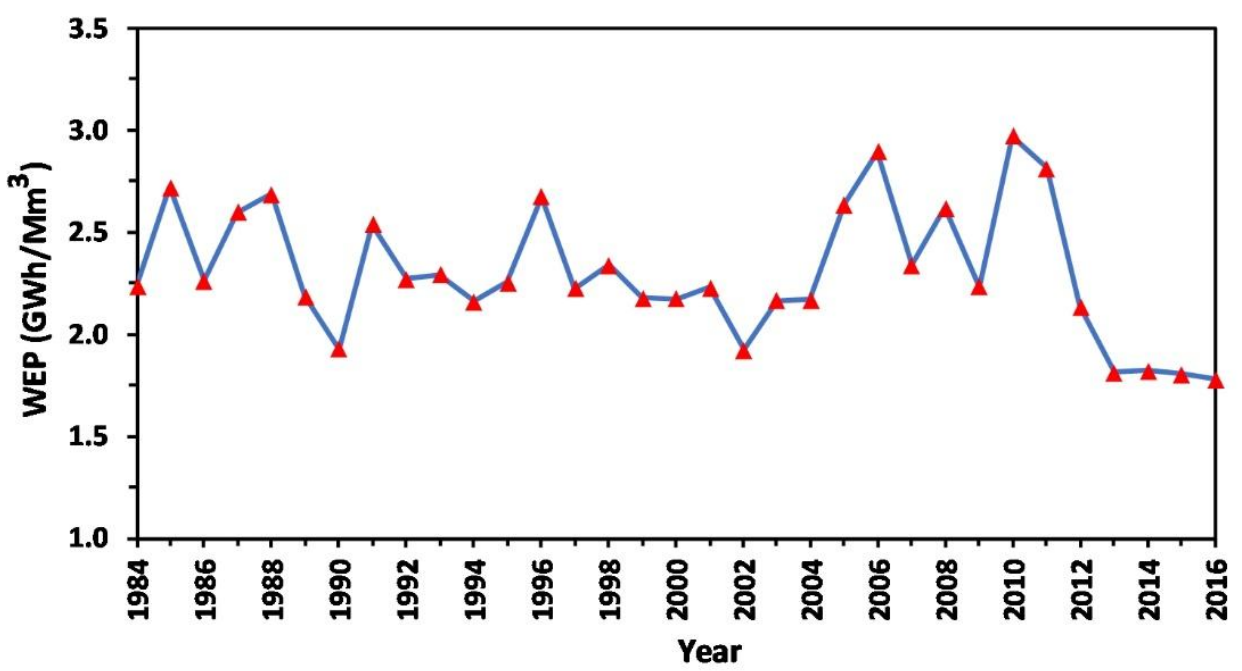

Fig. 7 Annual Water-Energy Productivity (WEP) of hydropower dams in the Lower Blue Nile Basin 

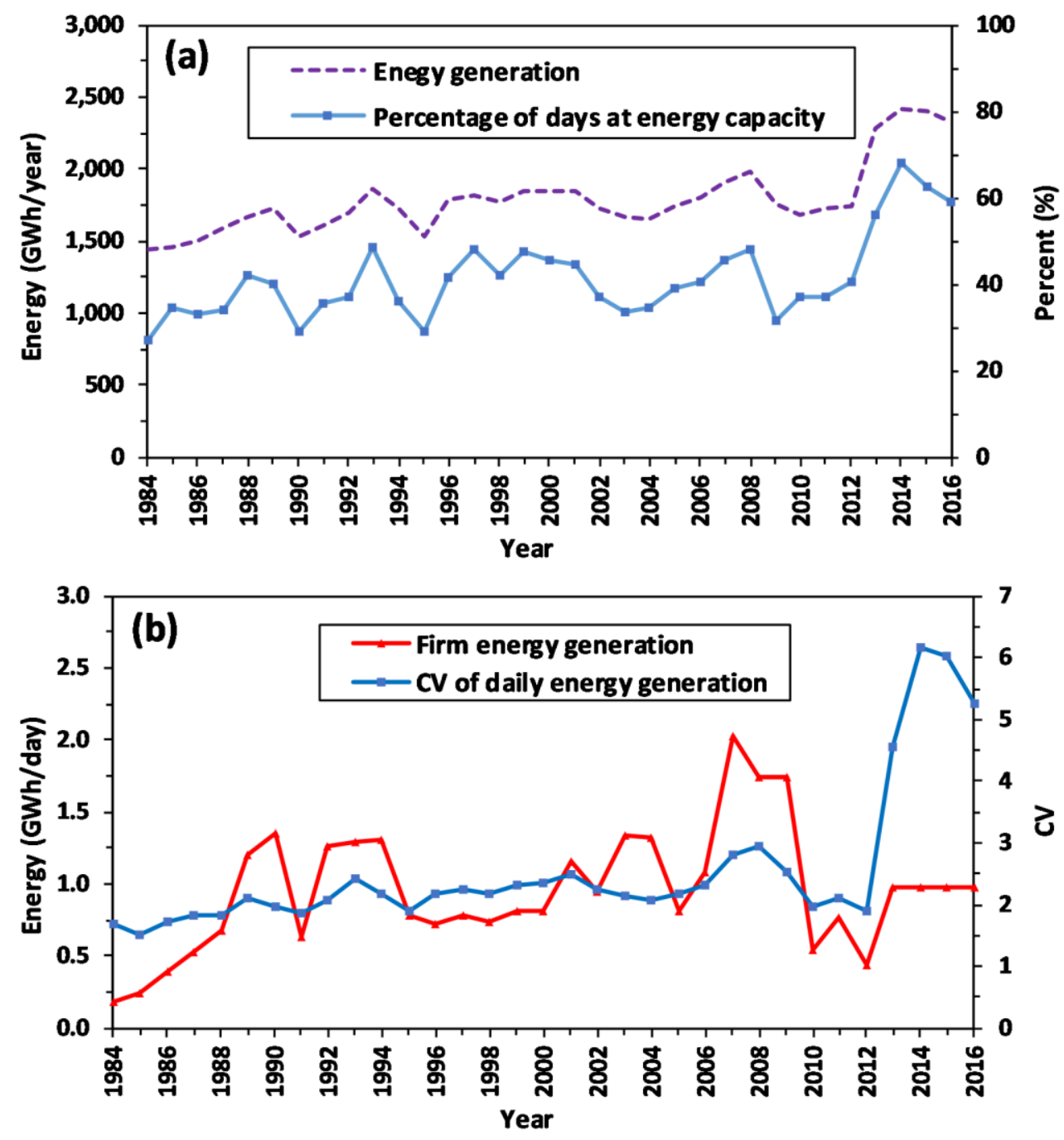

Fig. 8 Hydropower generation in the Lower Blue Nile Basin: (a) annual energy and percentage of days at energy capacity; (b) variability and firm energy.

Note: $\mathrm{CV}=$ Coefficient of Variation 

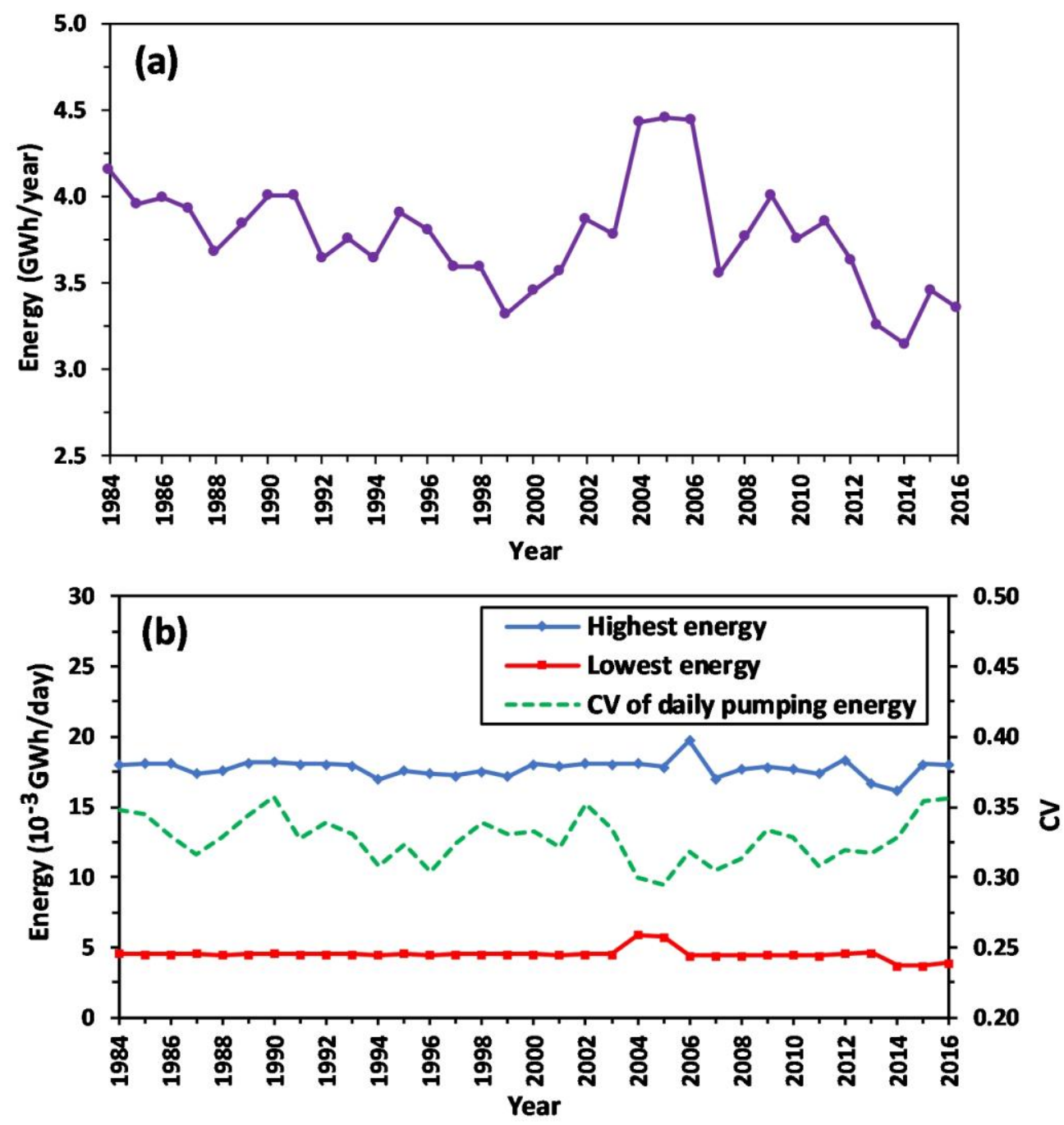

Fig. 9 Pumping energy in the Lower Blue Nile Basin: (a) annual energy; (b) highest energy, lowest energy, and variability.

Note: $\mathrm{CV}=$ Coefficient of Variation 
Table 1 Main features of the Roseires and the Sennar Dams

\begin{tabular}{|c|c|c|c|c|c|c|}
\hline Dam & $\begin{array}{l}\text { FSL } \\
(\mathrm{m} \text { asl) }\end{array}$ & $\begin{array}{l}\text { Storage at } \\
\text { FSL }\left(\mathrm{Mm}^{3}\right)\end{array}$ & $\begin{array}{l}\text { MOL } \\
\text { (m asl) }\end{array}$ & $\begin{array}{l}\text { Storage at } \\
\operatorname{MOL}\left(\mathrm{Mm}^{3}\right)\end{array}$ & Dam outlets & $\begin{array}{l}\text { Installed power } \\
\text { capacity (MW) }\end{array}$ \\
\hline Sennar & 421.7 & $\begin{array}{l}640 \\
\text { (in 1985) }\end{array}$ & 417.2 & $\begin{array}{l}220 \\
\text { (in 1985) }\end{array}$ & $\begin{array}{l}72 \text { gated } \\
\text { spillways, } 80 \\
\text { deep sluice gates } \\
\text { and } 2 \text { turbine } \\
\text { intakes }\end{array}$ & 15 \\
\hline $\begin{array}{l}\text { Roseires } \\
\text { (after } \\
\text { heightening) }\end{array}$ & 490 & $\begin{array}{l}5,909 \\
\text { (in 2012) }\end{array}$ & 469 & $\begin{array}{l}58.3 \\
\text { (in 2012) }\end{array}$ & $\begin{array}{l}5 \text { deep sluice } \\
\text { gates, } 7 \\
\text { spillways, and } 7 \\
\text { turbine intakes }\end{array}$ & 280 \\
\hline
\end{tabular}

Note: FSL = Full Supply Level; MOL = Minimum Operating Level

Table 2 Daily performance of the model in the calibration and validation periods.

\begin{tabular}{llllll}
\hline Location & $\begin{array}{l}\text { Performance } \\
\text { metric }\end{array}$ & Calibration & \multicolumn{3}{l}{ Validation } \\
\cline { 3 - 5 } & & Metric value & Ranking & Metric value & Ranking \\
\hline Rosieres & $\mathrm{R}^{2}$ & 0.97 & Excellent & 0.98 & Excellent \\
Dam & NSE & 0.96 & Excellent & 0.98 & Excellent \\
& MPE & 0.88 (range: 100 to -1152$)$ & Excellent & 0.84 & Excellent \\
Sennar & $\mathrm{R}^{2}$ & 0.95 & Excellent & 0.97 & Excellent \\
Dam & NSE & 0.95 & Excellent & 0.96 & Excellent \\
& MPE & -1.30 (range: 103 to -831$)$ & Excellent & 8.95 & Excellent \\
Khartoum & $\mathrm{R}^{2}$ & 0.90 & Excellent & 0.94 & Excellent \\
Gage & NSE & 0.90 & Excellent & 0.94 & Excellent \\
& MPE & 0.26 (range: 204 to -2705) & Excellent & -13.08 & Very good \\
\hline
\end{tabular}

Note: $\mathrm{R}^{2}=$ coefficient of determination; NSE = Nash-Sutcliffe coefficient of efficiency; MPE = Mean Percentage Error 
Table 3 Outlines of the operating rules of the Roseires and the Sennar dams.

\begin{tabular}{|c|c|c|c|c|}
\hline \multirow[t]{2}{*}{ Priority } & \multicolumn{2}{|c|}{ Before the heightening of the Roseires Dam } & \multicolumn{2}{|c|}{ After the heightening of the Roseires Dam } \\
\hline & Roseires & Sennar & Roseires & Sennar \\
\hline 1 & $\begin{array}{l}\text { Keeping the reservoir } \\
\text { above the minimum } \\
\text { operating level }\end{array}$ & $\begin{array}{l}\text { Keeping the reservoir } \\
\text { above the minimum } \\
\text { operating level }\end{array}$ & $\begin{array}{l}\text { Keeping the reservoir } \\
\text { above the minimum } \\
\text { operating level }\end{array}$ & $\begin{array}{l}\text { Keeping the reservoir } \\
\text { above the minimum } \\
\text { operating level }\end{array}$ \\
\hline 2 & $\begin{array}{l}\text { Keeping the reservoir } \\
\text { below the full supply } \\
\text { level }\end{array}$ & $\begin{array}{l}\text { Keeping the reservoir } \\
\text { below the full supply } \\
\text { level }\end{array}$ & $\begin{array}{l}\text { Keeping the reservoir } \\
\text { below the full supply } \\
\text { level }\end{array}$ & $\begin{array}{l}\text { Keeping the reservoir } \\
\text { below the full supply } \\
\text { level }\end{array}$ \\
\hline 3 & $\begin{array}{l}\text { Targeting certain water } \\
\text { levels starting from a } \\
\text { date between } \\
\text { September 1st and } \\
\text { September 26th. The } \\
\text { starting is related to the } \\
\text { flow at El-Diem Gage }\end{array}$ & $\begin{array}{l}\text { Targeting certain water } \\
\text { levels starting from a } \\
\text { date between } \\
\text { September } 1 \text { st and } \\
\text { September 26th. The } \\
\text { starting is related to the } \\
\text { flow at El-Diem Gage }\end{array}$ & $\begin{array}{l}\text { Targeting certain } \\
\text { water levels starting } \\
\text { from a date between } \\
\text { August } 11 \text { th and } \\
\text { September } 11 \text { th. The } \\
\text { starting is related to } \\
\text { the flow at El-Diem } \\
\text { Gage }\end{array}$ & $\begin{array}{l}\text { Targeting certain water } \\
\text { levels starting from a } \\
\text { date between August } \\
11 \text { th and September } \\
11 \text { th. The starting is } \\
\text { related to the flow at El- } \\
\text { Diem Gage }\end{array}$ \\
\hline 4 & $\begin{array}{l}\text { Keeping the reservoir } \\
\text { at the minimum } \\
\text { operating level from } \\
\text { June } 1 \text { st to September } \\
\text { 26th }\end{array}$ & $\begin{array}{l}\text { Keeping the reservoir } \\
\text { at the minimum } \\
\text { operating level from } \\
\text { June } 1 \text { st to September } \\
\text { 26th }\end{array}$ & $\begin{array}{l}\text { Keeping the reservoir } \\
\text { at the minimum } \\
\text { operating level from } \\
\text { June 1st to August } \\
\text { 10th }\end{array}$ & $\begin{array}{l}\text { Keeping the reservoir at } \\
\text { the minimum operating } \\
\text { level from June 1st to } \\
\text { August 10th }\end{array}$ \\
\hline 5 & $\begin{array}{l}\text { Meeting part of the } \\
\text { water demands of the } \\
\text { Lower Blue Nile }\end{array}$ & $\begin{array}{l}\text { Meeting part of the } \\
\text { water demands of the } \\
\text { Lower Blue Nile }\end{array}$ & $\begin{array}{l}\text { Meeting part of the } \\
\text { water demands of the } \\
\text { Lower Blue Nile }\end{array}$ & $\begin{array}{l}\text { Meeting part of the } \\
\text { water demands of the } \\
\text { Lower Blue Nile }\end{array}$ \\
\hline
\end{tabular}


Table 4 Regime shift and trend analyses of the water-energy indicators and measures.

\begin{tabular}{|c|c|c|c|c|c|c|c|}
\hline \multirow{2}{*}{$\begin{array}{l}\text { Indicator or } \\
\text { measure }\end{array}$} & \multicolumn{4}{|c|}{ Regime shift test } & \multicolumn{3}{|c|}{ Kendall tau test } \\
\hline & $\begin{array}{l}\text { Change } \\
\text { year }\end{array}$ & $\begin{array}{l}\text { Mean } \\
\text { before }\end{array}$ & $\begin{array}{l}\text { Mean } \\
\text { after }\end{array}$ & $\begin{array}{l}\text { Significance } \\
\text { level }\end{array}$ & Time span & $\begin{array}{l}\text { Trend } \\
\text { direction }\end{array}$ & $\begin{array}{l}\text { Significance } \\
\text { level, } p\end{array}$ \\
\hline \multirow{2}{*}{$\begin{array}{l}\text { Flow at El-Diem Gage } \\
\left(\mathrm{Mm}^{3} / \text { year }\right)\end{array}$} & 2006 & 47330 & 55938 & 0.0187 & $1984-2005$ & + & NS \\
\hline & & & & & 2006-2016 & - & NS \\
\hline WEP $\left(\mathrm{GWh} / \mathrm{Mm}^{3}\right)$ & 2013 & 2.37 & 1.80 & 0.0001 & 1984-2012 & - & NS \\
\hline \multirow{2}{*}{$\begin{array}{l}\text { Annual hydro-energy } \\
\text { (GWh) }\end{array}$} & 1996 & 1612 & 1784 & 0.0007 & 1984-1995 & + & 0.0092 \\
\hline & 2013 & 1784 & 2353 & 0.0001 & $1996-2012$ & - & NS \\
\hline $\begin{array}{l}\text { Days at energy } \\
\text { capacity }(\%)\end{array}$ & 2013 & 39 & 61 & 0.0012 & 1984-2012 & + & 0.0201 \\
\hline $\begin{array}{l}\text { Firm daily energy } \\
\text { (GWh) }\end{array}$ & - & - & - & - & $1984-2016$ & + & 0.0006 \\
\hline $\begin{array}{l}\text { CV of daily energy } \\
\text { generation }\end{array}$ & 2013 & 2.1 & 5.5 & 0.0024 & 1984-2012 & + & 0.0006 \\
\hline $\begin{array}{l}\text { Annual pumping } \\
\text { energy (GWh) }\end{array}$ & 2012 & 3.84 & 3.30 & 0.0003 & 1984-2011 & - & NS \\
\hline $\begin{array}{l}\text { Highest daily pumping } \\
\text { energy }(\mathrm{GWh})\end{array}$ & - & - & - & - & - & - & NS \\
\hline $\begin{array}{l}\text { Lowest daily pumping } \\
\text { energy }\left(10^{-3} \mathrm{GWh}\right)\end{array}$ & 2014 & 4.59 & 3.75 & 0.0003 & $1984-2013$ & - & NS \\
\hline \multirow{2}{*}{$\begin{array}{l}\text { CV of daily pumping } \\
\text { energy }\end{array}$} & 2004 & 0.33 & 0.31 & 0.0017 & $1984-2003$ & - & NS \\
\hline & 2014 & 0.31 & 0.35 & 0.0452 & 2004-2013 & + & NS \\
\hline
\end{tabular}

Note: $\mathrm{WEP}=$ water-energy productivity; $\mathrm{CV}=$ coefficient of variation; $\mathrm{NS}=$ Not significant at $\mathrm{p}=0.05$. 